\title{
Bartter Syndrome Represented by Recurrent Hypokalemia Attacks: A Case Report
}

\author{
Nuran Küçük, Esra Çelik Kuzaytepe, Esma Esmi, Şerife Dülger, Gökşen Erkin
}

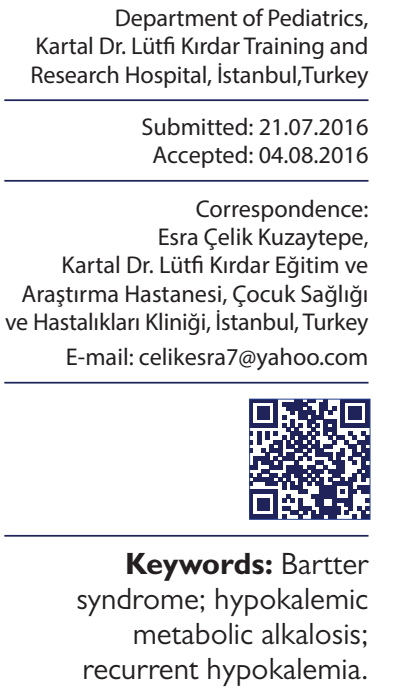

\begin{abstract}
Bartter syndrome is a tubular disorder and characterized with hypokalemia, hypokalemic metabolic alkalosis, hyperreninemia, normal blood pressure, increased loss of urinary sodium, potassium and chloride. Patients are generally detected with polyuria, dehydration, failure to thrive and electrolyte imbalance. Herein, we report a case that had Bartter syndrome represented by recurrent hypokalemia attacks without metabolic alkalosis.
\end{abstract}

\section{INTRODUCTION}

Bartter syndrome (BS) is characterized by insufficient sodium and chloride reabsorption from kidneys, hyperreninemia, hypokalemia metabolic alkalosis and it is a clinical and genetic disease in the group of tubulopathies. ${ }^{[1,2]}$ Clinically, patients visit hospital because of polyuria, polydipsia, growth retardation, life-threatening dehydration attacks, fever episodes and normal or low blood pressure. ${ }^{[3]}$

In this case report, a patient with recurrent hypokalemia attacks were presented.

\section{CASE REPORT}

A 2-year-6-month-old female patient was admitted our clinic because of constipation and fatigue. Her mother had a spontaneous vaginal delivery of her as a live born baby at the end of her third pregnancy. The baby weighed $5000 \mathrm{~g}$ as she was born and she was followed in a mechanic ventilator because of perinatal asfixia for one week. After fifteen days, she was discharged as a healthy baby. She has been using phenobarbital since that time and the development of the case was similar with her coevals. She was hospitalized nine times because of hypokalemia in the last year and she was discharged after the recovery by IV perfusion. During the last hospitalization, oral potassium treatment was started before discharge one month ago. However, her mother had not provided her medicine for one week. The physical examination of the case was normal except oral aft, her weight was in the $25-50^{\text {th }}$ percentile and her height was in the $75-90^{\text {th }}$ percentile. Laboratory values were detected as Serum K: $2.7 \mathrm{mmol} / \mathrm{L}, \mathrm{Na}: 138 \mathrm{mmol} / \mathrm{L} \mathrm{Ca:} 9.4 \mathrm{mg} / \mathrm{dl}, \mathrm{P}: 5.3 \mathrm{mg} /$ dl, Creatinine: $0.22 \mathrm{mg} / \mathrm{dl}$, BUN: $15 \mathrm{mg} / \mathrm{dl}$. Blood gas was detected as $\mathrm{pH}: 7.4 \mathrm{I}, \mathrm{pCO}_{2}: 32.5 \mathrm{mmHg}^{-} \mathrm{HCO}_{3}: 21.9$ $\mathrm{mmol} / \mathrm{L}, \mathrm{BE}:-3 \mathrm{mmol} / \mathrm{L}$. Urine output was polyuric (4.2 $\mathrm{cc} / \mathrm{kg} / \mathrm{hour}$ ), spot urine sodium, chloride and potassium excretions were increased. Renin and aldosterone levels were high and urinary ultrasonography was normal. The 
case was diagnosed as Bartter Syndrome. Firstly, parenteral and then oral potassium treatment ( $3 \mathrm{mEq} / \mathrm{kg} /$ day) was applied. Indomethacin ( I mg/kg/day) was started together with gastroprotective agent. Her blood gas analyses, serum potassium and other electrolytes stayed at normal levels with these medications and her polyuria reached to the normal standards. Since hypertension was detected in the two days after her hospitalization, her 24-hour urine sample was analyzed and in this test, the cortisol/ cortisone ratio was normal (0.4I). Additionally, her fundus examination for hypertensive rethinopathy was normal, and her echocardiography and electrocardiography was also normal. In her follow-ups, her blood pressure stayed in normal persentiles according to age. No genetic finding was detected in favor of Liddle syndrome and genetic mutation results which analyzing classical BS has not completed. The patient has been under treatment for six months now and she is still taking oral potassium chloride and indomethacin in the same dose; her last laboratory results were detected as Serum K: $3.9 \mathrm{mmol} / \mathrm{L}, \mathrm{Na}: 138$ $\mathrm{mmol} / \mathrm{L}$ Ca: $10.4 \mathrm{mg} / \mathrm{dl}$, Creatinine: $0.3 \mathrm{mg} / \mathrm{dl}$, BUN: 12 $\mathrm{mg} / \mathrm{dl}$. Her blood gas was measured as $\mathrm{pH}$ : 7.4I, $\mathrm{pCO}_{2}$ : $4 \mathrm{I} \mathrm{mmHg}, \mathrm{HCO}_{3}: 25.3$, BE: I.7 mmol/L. She did not have constipation or fatigue again. Informed consent was obtained from the parents of the patient.

\section{DISCUSSION}

Bartter syndrome is an autosomal recessive type of genetically transmitted disease which is found in a rare renal tubular disease group. It is characterized by urinary loss of sodium, potassium and chloride, hypokalemic metabolic alkalosis, high serum renin and aldosterone levels and secondarily, high prostaglandin levels in the blood and urine. Clinically, patients visit hospital because of polyuria, polydipsia, growth retardation, life-threatening dehydration attacks, fever episodes and normal or low blood pressure. ${ }^{[3]}$

Bartter syndrome occurs due to the mutations that inactivate the transporter proteins in the ascending limb of the loop of Henle (NKCC2, ROMK, CIC, Barttin, Ca2+sensitazing receptor). ${ }^{[1]}$ Generally, these mutations are not characterized clinically, but they cause severe malfunctions in the ascending limb of the loop of Henle. [4] The clinical and laboratory results of the cases with Bartter syndrome can be mixed with the cases who have Gitelman syndrome which is a kind of hereditary tubulus disfunction. The absence of hypocalciuria is one of the characteristics that differentiates Bartter syndrome from Gitelman syndrome. ${ }^{[4]}$ If hypertension accompanies to hypokalemia and metabolic alkalosis, Liddle syndrome, the autosomal dominant genetic disease characterized by variable levels of hypertension and hypokalemic metabolic alkalosis, should be thought. Patients are similar with the patients with primary hyperaldosteronism, however, their mineralcorticoid hormone levels do not increase. Therefore, it is called as pseudo-hyperaldosteronism. [5] Since the case had hypertension in the two days after hospitalization, genetic mutation analysis sent for Liddle syndrome was negative. Additionally, 24-hour urine sample was also analyzed to check the presence of Apparent Mineralcorticoid Excess (AME) syndrome which is known as a disruption of cortisol to cortisone conversion mechanism. In this syndrome, low renin and aldosterone levels accompany to hypertension and hyperkalemia. ${ }^{[6]}$ The results of 24-h-urine cortisol to cortisone was in normal range $(<3)$. Since her blood pressure values were stayed in normal range in the follow-ups, Liddle and AME syndrome possibilities were eliminated. In addition, Gitelman syndrome is usually seen at advanced ages and she had neither any electrolyte dysregulation except hypokalemia nor hypocalciuria. Therefore the case was considered as BS.

Since the tubular defect which causes Bartter syndrome cannot be corrected, main treatment is life-long usage of potassium chloride replacement and non-steroid inflammatory drugs to minimize the effects caused by the increase of the prostaglandin and aldosterone production. ${ }^{[4]}$ In some cases, a potassium-sparing diuretic such as spironolactone or amiloride can be used or some COX-2 inhibitors such as celecoxibe can also be tried because of the gastrointestinal side effects of indomethacin. ${ }^{[3]}$ In our case, indomethacin and oral potassium supplement were enough and she did not have a hypokalemia attack again. Consequently, although they do not have metabolic alkalosis and even if they have normal chloride levels, we suggest to consider BS in the cases with repetitive hypokalemia.

Authorship contributions

Concept: N.K.; Design: N.K., E.Ç.K.; Data collection \&/ or processing: N.K.; Analysis and/or interpretation: N.K.; Literature search: N.K.; Writing: N.K., E.Ç.K.; Critical review: N.K.

Conflict of interest

None declared.

\section{REFERENCES}

1. Xiumin W, Zheng S, Meichun X, Junfen F, Li L. A Chinese Girl with Bartter Syndrome Type III due to a Novel Mutation and/or Single Nucleotide Polymorphisms (SNPs) in CLCNKB Gene. Iran J Pediatr 2013;23:89-94.

2. Kim JB. Channelopathies. Korean J Pediatr 2014;57:1-18. [CrossRef]

3. Nascimento CL, Garcia CL, Schvartsman BG, Vaisbich $\mathrm{MH}$. Treatment of Bartter syndrome. Unsolved issue. J Pediatr (Rio J) 2014;90:512-7. [CrossRef]

4. Tekçe BK, Tekçe H, Dağıstan Y, Çolak HB. A case of Bartter syndrome presenting with atypical clinical manifestations. Tepecik 
Eğitim ve Araştırma Hastanesi Dergisi 2015;25:58-61.

5. Şit D, Yllmaz ME. Liddle's syndrome, bartter syndrome and gitelman's variant. Turkiye Klinikleri J Int Med Sci 2007;3:49-56.
6. Stewart PM, Corrie JE, Shackleton CH, Edwards CR. Syndrome of apparent mineralocorticoid excess. A defect in the cortisol-cortisone shuttle. J Clin Invest 1988;82:340-9. [CrossRef]

Tekrarlayan Hipokalemi Atakları İle Seyreden Bartter Sendromu: Olgu Sunumu

Bartter sendromu hipokalemi, hipokloremik metabolik alkaloz, hiperreninemi, normal kan basıncı, idrarda sodyum, potasyum ve klor atılımının artması ile karakterize tübüler bir hastalıktır. Olgular genellikle erken çocukluk döneminde poliüri, dehidratasyon, büyüme-gelişme geriliği, elektrolit imbalansı ile saptanırlar. Bu yazıda, metabolik alkozu olmadan, tekrarlayan hipokalemi ataklarılla seyreden Bartter sendromlu bir olgu sunuldu.

Anahtar Sözcükler: Bartter sendromu; hipokalemik metabolik alkaloz; tekrarlayan hipokalemi. 